Author: ES Nwauche

PROTECTING EXPRESSIONS OF FOLKLORE WITHIN THE RIGHT TO

CULTURE IN AFRICA

ISSN 1727-3781

2010 VOLUME 13 No 4 


\section{PROTECTING EXPRESSIONS OF FOLKLORE WITHIN THE RIGHT TO CULTURE IN AFRICA}

\section{ES Nwauche*}

Introduction

Expressions of folklore ${ }^{1}$ produced by communities in their interaction with their environment can be protected within the individually oriented intellectual property law paradigm or by a sui generis model. The additional possibility that an effective protection of expressions of folklore could wholly or partially be facilitated by a human rights framework, especially by the right to culture, appears not to have been seriously considered especially when the debate continues to rage $^{2}$ as to whether intellectual property rights are part of or different from human rights. If the conceptual basis of intellectual property - protecting individual intellectual capital - and human rights is not very clear, it should not be surprising that the idea that human rights can protect expressions of folklore would appear to be unlikely.

In recent years three issues revolving around the right to culture have propelled the possibility of a virile human rights protection of expressions of folklore to the front burner. The first is an increased understanding of the right to culture in national

* Enyinna Sodienye Nwauche. LLB LLM BL. Director Centre for African Legal Studies, Port Harcourt Nigeria and Associate Professor, Department of Business Law, Rivers State University of Science and Technology Port Harcourt Nigeria. (enyinnanwauche@yahoo.com)This is a revised version of a presentation to a Conference on Traditional Knowledge in Legal Context, 1718 March 2009 at the Potchefstroom Campus of the Northwest University South Africa.

1 For the purposes of this paper a definition of expressions of folklore that appears suitable is the one adopted by the World Intellectual Property Organisation (hereafter WIPO) Intergovernmental Committee on Intellectual Property Traditional Knowledge and Expressions of Folklore in the Draft Treaty on the Protection of Expressions of Folklore. Expressions of folklore are defined as: "Productions consisting of characteristic elements of the traditional cultural heritage developed and maintained by a community, or by individuals reflecting the traditional artistic expectations of such a community. Such productions may include, for example, the following forms of expressions, or combinations thereof: (i) verbal expressions, such as folk tales, folk poetry and riddles; aspects of language such as words, signs, names, symbols and other indications; (ii) musical expressions, such as folk songs and instrumental music; (iii) expressions by action, such as folk dances, plays and artistic forms or rituals; whether or not reduced to a material form; and (iv) tangible expressions, such as: (a) productions of folk art, in particular, drawings, designs, paintings, carvings, sculptures, pottery, terracotta, mosaic, woodwork, metalware, jewelry, basket weaving, handicrafts, needlework, textiles, carpets, costumes; (b) musical instruments; (c) architectural forms." The Draft Treaty is available at WIPO 1984 www.wipo.int.

2 See generally Yu 2007 Ga S U L Rev 709; Helfer 2007 UC Davis L Rev 971. 
constitutions and the recognition that customary law is a manifestation of the right to culture. The second is an expanded understanding of the substantive content of Article 15(1) of the International Covenant for Economic Social and Cultural Rights ${ }^{3}$ as part of the right to culture, while the third is the recognition of the rights of indigenous peoples marked significantly by the 2007 United Nations Declaration of the Rights of Indigenous People. ${ }^{4}$ These three issues are not evidence that the human rights protection of expressions of folklore is a recent phenomenon. Like most other human rights narratives it has been ongoing, even if not properly recognised.

At the heart of the ability of the right to culture to protect expressions of folklore is the extent that a State will recognise and affirm that groups like individuals can hold and exercise control and management over their intellectual capital, including expressions of folklore. This would mean that the group or community, as against the individual, would be in a position to decide how third parties use their expressions of folklore. It is thus plausible that any mechanism within a State that enables communities to protect their intellectual capital contributes to the protection of their right to culture.

The title of the paper suggests that there is something unique about the protection of expressions of folklore in Africa. There are a number of reasons why this is so. First is the fact that a distinct African human rights regime which is built around the African Charter on Human and Peoples' Rights recognises group rights, which recognition includes the right of communities to their cultural development, including the protection of their intellectual capital. The second commonality is that the commonly understood notion of indigenous peoples is largely absent in Africa. In these countries there are no groups who were already occupying territories that were conquered by other groups, as is evident in Australia, and North and South America. In Africa there are groups who joined as equals upon the independence of these African States. However, on the basis of relative size of population groups and their ability to influence power relations in a State, there are minorities. It appears better, however, to speak of communities in the understanding of how communal intellectual 
property can be protected. The third commonality is the low level of intellectual property protection in African States. This has a bearing on the ability of these States to effectively protect expressions of folklore. It must be remembered that Africa's rich communal intellectual capital is a staple for individual intellectual property protected by national intellectual property regimes. It is therefore a challenge to balance access to the creative reserve of communal intellectual property and the protection that it deserves. Fourthly, African States are multi-ethnic in composition, with the possibility that a protection regime may lead to conflicts as to which ethnic group really owns an expression of folklore.

I have organised this article as follows. In part one I examine the right to culture and the juridical basis for the protection of expressions of folklore. In part two I consider the protection of expressions of folklore in African States, examine the increasing understanding of how Article 15 of the ICESCR protects expressions of folklore; determine how the UNESCO Convention on the Diversity of Cultural Expressions ${ }^{5}$ can serve as a juridical basis for the protection of expressions of folklore, and analyse how the rights of indigenous peoples affects Africa. In part three I undertake an overview of the protection of expressions of folklore by intellectual property law and also by sui generis models in Africa. I make some concluding remarks in part four.

\section{A human rights framework for the protection of expressions of folklore - the right to culture}

At the centre of the protection of expressions of folklore is the right to culture. In the context of our discussions, it is the right of communities to protect their expressions of folklore because it seems to be beyond argument that expressions of folklore are a fundamental part of the cultures of a people.

To be able to understand how the right of culture may perform such a task as outlined above, it is important to realise at the outset that culture has many meanings, a fact that affects the nature of this protection. O'Keefe states that the

$5 \quad$ Hereafter UNESCO Convention. 
word "culture" refers to three distinct but overlapping and equally valid concepts, which are:

(1) "culture" in the classic highbrow sense, meaning the traditional canon of art, literature, music, theatre, architecture and so on;

(2) "culture" in a more pluralist sense, meaning all those products and manifestations of creative and expressive ideas a definition which encompasses not only 'high' culture but also more mass phenomena such as commercial television and radio, the popular press, contemporary or folk music, handicrafts and organized sports; and

(3) "culture" in the anthropological sense, meaning not simply the products or artefacts of creativity and expression (as envisaged in the first two definitions) but rather, a society's underlying and characteristic pattern of thought - its "way of life" from which these and all social manifestations spring. ${ }^{6}$

With respect to the first and second view of culture, "... the right to culture would mean the equal rights of individuals to have access to the accumulated cultural capital. An extension of this view is the right to cultural development." 7 The first two views can also support the position that the right to culture means the right of individuals to freely create their culture and the right of all persons to enjoy a free access to these creations. ${ }^{8}$ This view of culture would support creativity and intellectual property rights which are primarily designed to protect the creative processes in a community. The third view recognises that culture establishes a community's identity and distinguishes it from other communities. A right to culture in this sense is for the individuals in that community as well as for the community itself. For the individuals, it is a right to be enjoyed in community with others, since it enables them to be unique and identified by third parties. For the community, it recognises that it is important for the community to maintain its cultural identity by exclusively determining if and how its members and third parties have access to their culture, and the context in which third parties use, interpret, re-interpret and develop their cultural capital. This view of the right to culture therefore privileges group rights over individual rights. Giving groups this position enables them to act in a way that may deny the rights of individuals which appears worrisome from a liberal point of

O'Keefe 1998 ICLQ 905.

Stavenhagen "Cultural Rights and Universal Human Rights" 65-67.

See generally Coombe 1998 Ind J of Global Leg Stud. 
view. ${ }^{9}$ The right to culture often involves a clash between universality and relativism because the post world war human rights system is built around the individual as an end worth protecting. While the rights are vested in an individual irrespective of his identity and are therefore universal, collective and group rights are relative to the particular ethnic cultural or religious community. The conflict in this area arises because of the possibility that an individual may find certain parts of his culture offensive and may therefore reject these offensive parts while still identifying with the group. A culturally relative human rights regime on the other hand recognises the right of a group to maintain its cultural identity and insists that its members must conform without exception. If the truth be told, most human rights regimes reflect both perspectives in different mixes. The intellectual property rights regime is largely built to protect individual intellectual capital but is also a balance between the private interests of a creator and the public interest. This is true of copyright as with other intellectual property rights such as patents and designs. These rights grant the individual exclusive rights to determine how third parties, including his community, have access to his intellectual capital. His exclusive rights are not total, however. In certain circumstances the public is given access to his intellectual capital. On the other hand, the recognition of a community's right to the control and management of its intellectual capital is not total or exclusive. While in many circumstances the community will deny access to or determine the terms of the use of its intellectual capital there are other circumstances in which members of the community and third parties must be able to have access to this intellectual capital. A good reason why this must be so is to ensure the realisation of individual fundamental human rights. Thus members of a group would protect their intellectual capital in furtherance of their human rights, even if this entails a reproduction of their community's intellectual capital. This possibility recognises that no human right is absolute and that the exercise of all rights including collective and group rights must be balanced with the exercise of other rights. It is important to reiterate that the concept of a collective or group right does not imply exclusivity. ${ }^{10}$ Collective and group rights recognise and define how a group may serve to protect its intellectual capital. It would be wrong because of the potential for abuse for collective rights to give way to "... collective

Margalit and Halbertal 1994 Social Research 529.

Graber "Traditional Cultural Expressions" 67. 
dimensions of individual rights."11 States have not taken away the rights of individuals because of the potential for abuse. It must be realised that it seems wrong for an individual to seek unrestricted access to a communal creation in the same way that it would be wrong for an individual to seek unrestricted access to the intellectual capital of another person. This possibility must depend on a balance between the individual and group entitlements and can be resolved through the mechanism of national human rights regimes, all of which have limitation mechanisms. ${ }^{12}$ The manner in which this can take place is further discussed in the latter part of this article.

The objective of this article assumes the anthropological view of culture and explores how expressions of folklore can be managed by communities and groups. Expressions of folklore refer to the manifestations of the interaction of members of a community with one another and their environment in a way that constitutes and represents their identity. Expressions of folklore are therefore part of the totality of the experience of a people, which represents the culture of a people. They are intrinsic in the communities which, like individuals, are worthy of protection. In fact, it can be argued that communities provide the context for the realisation of individual self worth. Communities enable individuals to define and nurture themselves. ${ }^{13} \mathrm{An}$ individual's self-esteem or worth is greatly affected by the manner in which his community is treated for the reason that his identity and the way people react to this identity is therefore affected. If this argument is clear with respect to discrimination on the grounds of religion, race, ethnic group and gender, it is less so with intellectual capital. With respect to intellectual capital it is true that we will instinctively react to the distortion of the intellectual capital of communities but may wonder at why such capital even in its authentic context should not be available for our use.

Graber "Traditional Cultural Expressions" 67.

In Nwauche 2005 Script-ed I undertake a preliminary examination of the use of S 36 of the Constitution of the Republic of South Africa, 1996 in the protection of the expressions of folklore.

13 See generally Kymlicka Multicultural Citizenship. 


\subsection{The international and African recognition of the right to culture}

The international framework for the protection of human rights that emerged after the Second World War through the International Bill of Rights - the Universal Declaration of Human Rights, ${ }^{14}$ the ICESCR and the International Covenant on Civil and Political Rights $^{15}$ - recognises collective and group rights. The UDHR in Article 27 provides that:

1. Everyone has the right freely to participate in the cultural life of the community, to enjoy the arts and to share in scientific advancement and its benefits.

2. Everyone has the right to the protection of the moral and material interests resulting from any scientific, literary or artistic production of which he is the author.

Cultural rights acquired a treaty-binding character in the ICCPR and ICESCR. Article 1(1) of the ICESCR provides that: "All peoples have the right of self-determination. By virtue of that right they freely determine their political status and freely pursue their economic, social and cultural development." Article 15 of the ICESCR further states that:

1. The States Parties to the present Covenant recognize the right of everyone:

(a) To take part in cultural life;

(b) To enjoy the benefits of scientific progress and its applications;

(c) To benefit from the protection of the moral and material interests resulting from any scientific, literary or artistic production of which he is the author.

2. The steps to be taken by the States Parties to the present Covenant to achieve the full realization of this right shall include those necessary for the conservation, the development and the diffusion of science and culture.

3. The States Parties to the present Covenant undertake to respect the freedom indispensable for scientific research and creative activity.

4. The States Parties to the present Covenant recognize the benefits to be derived from the encouragement and development of international contacts and co-operation in the scientific and cultural fields. 
Article 27 of the ICCPR provides that:

In those States in which ethnic, religious or linguistic minorities exist, persons belonging to such minorities shall not be denied the right, in community with the other members of their group, to enjoy their own culture, to profess and practise their own religion, or to use their own language.

It appears clearly from the cast of the ICESCR and ICCPR that they protect group rights as in Aarticle 1 of both treaties. On the other hand Article 27 of the ICCPR and Article 15 of the ICESCR recognise the collective rights of individuals in that they can exercise their rights in community with other persons. This schema is also present on a regional basis in Africa. It would be correct to assert that:

... Article 15 of the ICESCR can be seen as a general normative framework for a catalogue of cultural rights, but it only enumerates four categories of rights without specifically laying out what the concrete entitlements of those categories are. ${ }^{16}$

On a regional basis ${ }^{17}$ the African Charter on Human and Peoples' Rights also makes provisions for collective and group cultural rights. Article 17(2) of the Charter provides that every person shall freely take part in the cultural life of his community. Article 22 of the Charter further provides that all peoples shall have the right to their economic, social and cultural development with due regard to their freedom and identity and in the equal enjoyment of the common heritage of mankind. To strengthen the rights of groups to cultural development Article 18(3) provides that States are to promote and protect morals and traditional values recognised by the

\footnotetext{
See Niec 2002 www.dba.es

A number of other regional instruments make provision for the right to culture. First, A 13, paragraph 2, of the American Declaration of the Rights and Duties of Man of 1948: "Every person has the right to take part in the cultural life of the community, to enjoy the arts, and to participate in the benefits that result from intellectual progress, especially scientific discoveries. He likewise has the right to the protection of his moral and material interests as regards his inventions or any literary, scientific or artistic works of which he is the author." Second, A 14, paragraph 1(c), of the Additional Protocol to the American Convention on Human Rights in the Area of Economic, Social and Cultural Rights of 1988 ("Protocol of San Salvador"): "1. The States Parties to this Protocol recognize the right of everyone: a. To take part in the cultural and artistic life of the community; b. To enjoy the benefits of scientific and technological progress; c. To benefit from the protection of moral and material interests deriving from any scientific, literary or artistic production of which he is the author." Third, A 1 of Protocol No. 1 to the Convention for the Protection of Human Rights and Fundamental Freedoms of 1952 (European Convention on Human Rights): "Every natural or legal person is entitled to the peaceful enjoyment of his possessions. No one shall be deprived of his possessions except in the public interest and subject to the conditions provided for by law and by the general principles of international law."
} 
community. It is beyond doubt that the African Charter truly recognises group rights to culture in addition to recognising the individual right to culture.

The task of providing some content for the right to culture as it relates to expressions of folklore has begun at the international and regional levels. In this regard three documents are of importance. The first is a document of the Committee on Economic Social and Cultural Rights, ${ }^{18}$ viz. General Comment ${ }^{19}$ No 17: The Right of Everyone to Benefit from the Protection of the Moral and Material Interests Resulting from any Scientific, Literary or Artistic Production of Which He or She is the Author (Art. 15, Para. 1(c) of the Covenant). ${ }^{20}$ The second is the UNESCO Convention and the third document is the DRIP. I shall now examine each of these documents in some detail.

\subsubsection{CESCR GC No 17}

The scope of CESCR GC No $17^{21}$ can be found in paragraph 1 of the document:

The right of everyone to benefit from the protection of the moral and material interests resulting from any scientific, literary or artistic production of which he or she is the author is a human right, which derives from the inherent dignity and worth of all persons. This fact distinguishes article 15, paragraph 1 (c), and other human rights from most legal entitlements recognized in intellectual property systems. Human rights are fundamental, inalienable and universal entitlements belonging to individuals and, under certain circumstances, groups of individuals and communities. ${ }^{22}$

Paragraph 8 of CESCR GC No 17 defines "everyone" in Article 15(1)(c) to include communities or groups of individuals:

Although the wording of article 15, paragraph 1 (c), generally refers to the individual creator ("everyone", "he", "author"), the right to benefit from the protection of the moral and material interests resulting from one's scientific, literary or artistic productions can, under certain circumstances, also be enjoyed by groups of individuals or by communities.

\footnotetext{
18 Hereafter CESCR. The General Comments of the CESCR are important as they provide guidance to State parties to the ICESCR as to the nature and meaning of the ICESCR.

Hereafter GC.

Hereafter referred to as CESCR GC No 17.

Available at OHCHR CESCR www.ohchr.org

Emphasis added.
} 
The meaning of scientific literary or artistic production is explained thus:

Any scientific, literary or artistic production", within the meaning of article 15, paragraph 1 (c), refers to creations of the human mind, that is to "scientific productions", such as scientific publications and innovations, including knowledge, innovations and practices of indigenous and local communities, and "literary and artistic productions", such as, inter alia, poems, novels, paintings, sculptures, musical compositions, theatrical and cinematographic works, performances and oral traditions. ${ }^{23}$

The CESCR outlines the general legal obligations of State Parties in paragraph 28:

The right of everyone to benefit from the protection of the moral and material benefits resulting from any scientific, literary or artistic production of which he or she is the author, like all human rights, imposes three types or levels of obligations on States parties: the obligations to respect, protect and fulfil. The obligation to respect requires States parties to refrain from interfering directly or indirectly with the enjoyment of the right to benefit from the protection of the moral and material interests of the author. The obligation to protect requires States parties to take measures that prevent third parties from interfering with the moral and material interests of authors. Finally, the obligation to fulfil requires States parties to adopt appropriate legislative, administrative, budgetary, judicial, promotional and other measures towards the full realization of article 15, paragraph 1 (c).

Specific legal obligations with regard to what the CESCR describes as the "right to benefit from the protection of the moral and material interests resulting from any scientific, literary or artistic production of indigenous peoples" can be found in paragraph 32. The Committee recommends that States adopt measures to ensure the effective protection of the interests of indigenous peoples, taking into account the preferences of these peoples. A protection framework is recommended by the Committee, whose features might include:

a) measures to recognise, register and protect the individual or collective authorship of indigenous peoples under national intellectual property rights regimes;

b) measures that prevent the unauthorised use by third parties of the scientific, literary and artistic productions of indigenous peoples;

23 Emphasis added. 
c) the principle of free, prior and informed consent of the indigenous authors concerned; (iv) respect for the oral or other customary forms of transmission of their indigenous peoples' intellectual productions; and

d) the collective administration by indigenous peoples of the benefits derived from their productions.

These features of a protection framework seem really to speak to the protection of expressions of folklore within an intellectual property regime even though they may in some form qualify as part of a sui generis protection. In a sense this protection framework is already in existence in many States, including African countries that have adopted a property paradigm as the most effective means of protecting expressions of folklore. What CESCR GC No 17 may be said to have accomplished is the affirmation that communities, including indigenous peoples, have a right to the protection of their intellectual productions based on Article 15(1)(c). The significance of this assertion lies in the fact that the Draft General Comment 17 did not include communities in its contemplation of the beneficiaries of this right. It also appears inevitable that the protective regime that CESCR GC No 17 recommends is that of an intellectual property law, especially copyright. This is clear from the need to respect the oral and customary means of transmission, which would appear to be a reaction against the problems of fixation due to the oral nature of expressions of folklore. This appears to be a serious problem. The use of the intellectual property law paradigm is not inevitable, and even if this appears so, the strong possibility exists that its features in a well modulated context would recognise the consequences of the endowment of a right. A principal example is a substantial autonomy over the manner in which the intellectual production of communities is managed. As I shall examine later in this article, one of the principal flaws in the model laws and its municipal African expressions is the patronising manner in which the exercise of the management of expressions of folklore is vested in national copyright bodies. Implicit in this perspective is a wrong notion that communities, including indigenous peoples, are unable to manage their intellectual capital. Its substantive content is a choice which does not fully recognise the autonomy of indigenous peoples. The lack of substantial autonomy is also evident in the fact that CESCR GC No 17 makes no reference to the customary laws and protocols which are an intrinsic part of the intellectual capital of communities. What CESCR GC No 
17 recognises is a customary practice which is, as stated above, the need to overcome the obstacle posed by the oracular nature of expressions of folklore. The recognition that States should "respect the principle of free prior and informed consent" may appear as an example of the recognition of a substantial autonomy for indigenous peoples, even though it would be different if local communities were given the exclusive right to decide what to do with their intellectual productions. It may well be pointed out that States are also to recognise and register these intellectual productions and that this will enhance the autonomy of communities. It is well to remember that registration is not synonymous with exclusivity and that having exclusive rights over their intellectual productions will determine the nature of the rights which flow from registration. A substantial erosion of the autonomy of communities is that without exclusive rights CESCR GC No 17 recommends "collective administration" by indigenous peoples of the benefits of their intellectual productions. The recourse to collective administration as a means of resolving some of the problems of the protection of expressions of folklore must be treated with great caution. It assumes that all communities want monetary reward for the use of their expressions of folklore. Even though it is plausible that many communities look to economic returns for the appropriation of their intellectual capital, it would appear that the nature of collective administration, if not carefully thought out, would render all intellectual capital of communities usable for a fee. The moral rights of communities and the contextual integrity of expressions of folklore would be lost.

Another profound achievement of CESCR GC No 17 is the recognition that the cultural rights of communities are not absolute. Paragraph 22 of CESCR GC No 17 makes Article 15(1)(c) rights subject to limitations and must be balanced with the other rights recognised in the ICESCR. These limitations must be determined by law in a manner compatible with the nature of these rights, must pursue a legitimate aim, and must be strictly necessary for the promotion of the general welfare in a democratic society, in accordance with Article 4 of the ICESCR. Paragraph 23 provides that limitations must be proportionate, meaning that the least restrictive measures must be adopted when several types of limitations may be imposed. Limitations must be compatible with the very nature of the rights protected in Article $15(1)(c)$, which lies in the protection of the personal link between the communities and their creation and of the means which are necessary to enable communities to 
enjoy an adequate standard of living. CESCR GC No 17 further requires in paragraph 24 that the imposition of limitations may, under certain circumstances, require compensatory measures, such as payment of adequate compensation for the use of scientific, literary or artistic productions in the public interest.

\subsubsection{The UNESCO Convention on the Protection of the Diversity of Cultural Expressions}

On the 18 March 2007 the UNESCO Convention ${ }^{24}$ entered into force, three months after the thirtieth instrument of ratification was deposited. Adopted in 2005 by a vote of 148 to 2 , the Convention is steadily growing in importance, given the fact that the European Union and ninety-eight other countries, including twenty-five African countries, ${ }^{25}$ have adopted it. Essentially the Convention seeks to protect and promote the diversity of cultural expressions within territories of member states against the sweeping tide of globalisation. The objectives of the UNESCO Convention are as follows: Article 1 lists the objectives of the Convention. They are:

a) to protect and promote the diversity of cultural expressions;

b) to create the conditions for cultures to flourish and to freely interact in a mutually beneficial manner;

c) to encourage dialogue among cultures with a view to ensuring wider and balanced cultural exchanges in the world in favour of intercultural respect and a culture of peace;

d) to foster interculturality in order to develop cultural interaction in the spirit of building bridges among peoples;

e) to promote respect for the diversity of cultural expressions and raise awareness of its value at the local, national and international levels;

f) to reaffirm the importance of the link between culture and development for all countries, particularly for developing countries, and to support actions undertaken nationally and internationally to secure recognition of the true value of this link;

24 Paris 20 October 2005. The text of Convention is available at UNESCO 2005 www.unesco.org. Hereafter UNESCO Convention.

25 Benin, Burkina Faso, Burundi, Cameroon, Chad, Congo, Cote d' Ivoire, Djibouti, Egypt, Ethiopia, Gabon, Guinea, Kenya, Madagascar, Mali, Mauritius, Mozambique, Namibia, Niger, Nigeria, Senegal, South Africa, Togo, Tunisia and Zimbabwe. 
g) to give recognition to the distinctive nature of cultural activities, goods and services as vehicles of identity, values and meaning;

h) to reaffirm the sovereign rights of States to maintain, adopt and implement policies and measures that they deem appropriate for the protection and promotion of the diversity of cultural expressions on their territory; and

i) to strengthen international cooperation and solidarity in a spirit of partnership with a view, in particular, to enhancing the capacities of developing countries in order to protect and promote the diversity of cultural expressions.

The rights and obligations of State Parties, which are elaborated in Article 6, seem ideally contemplated within the framework of a State's cultural policies and measures. ${ }^{26}$ Each State Party is allowed to adopt measures aimed at protecting and promoting the diversity of cultural expressions within its territory. It is important to note that these measures are not restricted to cultural policies, but encompass all measures which may include the following:

a) regulatory measures aimed at protecting and promoting diversity of cultural expressions;

b) measures that, in an appropriate manner, provide opportunities for domestic cultural activities, goods and services among all those available within the national territory for the creation, production, dissemination, distribution and enjoyment of such domestic cultural activities, goods and services, including provisions relating to the language used for such activities, goods and services;

c) measures aimed at providing effective access to the means of production, dissemination and distribution of cultural activities, goods and services for domestic independent cultural industries and activities in the informal sector;

d) measures aimed at providing public financial assistance;

e) measures aimed at encouraging non-profit organisations, as well as public and private institutions and artists and other cultural professionals, to develop and promote the free exchange and circulation of ideas, cultural expressions

26 A 4(6) of the UNESCO Convention provides that "Cultural Policies and Measures" refers to "those policies and measures relating to culture, whether at the local, national, regional or international level, that are either focused on culture as such or are designed to have a direct effect on cultural expressions of individuals, groups or societies, including on the creation, production, dissemination, distribution of and access to cultural activities, goods and services." 
and cultural activities, goods and services, and to stimulate both the creative and entrepreneurial spirit in their activities;

f) measures aimed at establishing and supporting public institutions, as appropriate;

g) measures aimed at nurturing and supporting artists and others involved in the creation of cultural expressions; and

h) measures aimed at enhancing the diversity of the media, including through public service broadcasting.

Article 7 of the Convention permits State Parties to adopt measures to promote cultural expressions, which should provide an environment in their countries which encourages individuals and social groups to create, distribute and have access to their own cultural expression, paying due attention to the special circumstances and needs of women as well as various social groups, including indigenous people and persons belonging to minorities. A related provision of the Convention is Article 13, which encourages State Parties to endeavour to integrate culture in their development policies at all levels, for the creation of conditions conducive to sustainable development and, within this framework, to foster developments relating to the protection and promotion of the diversity of cultural expressions. Attention must be drawn to Article 8 of the Convention, which provides that in peculiar situations a State Party may adopt special measures to protect cultural expressions in its territory that are at risk of extinction, under serious threat, or otherwise in need of urgent safeguarding.

There is no doubt that the Convention is a strong tool for helping countries such as African States to develop their national cultural capacity. In this regard, it must be noted that the Convention permits States to deploy "all" measures to develop their cultural industries and their creative capacity. Thus, these measures can be in any sector, provided they have an impact on the cultural sector. This is important in Africa, as it may induce governments to think of culture not only as a facilitator but also as a mainstream development pillar. While it is true that the obligations incurred by States are discretionary, it is important that African countries feel obliged to introduce the measures in the Convention if it is to be of any use to them. In introducing these measures, the fundamental challenge of the right to culture must 
be accommodated. The national cultural capital of African States is the sum total of the intellectual capital of their communities. A good percentage of the individual intellectual activities deploy the rich cultural motifs of these communities. A good example is the African film industry, which is buoyant in Nigeria, Ghana, Tanzania, Uganda, and South Africa, among other African countries. Those individuals who exploit the cultural motifs of their communities or of other communities in their country are exercising their rights, including the right to culture and the freedom of expression. In order to encourage these national endeavours a balance must be sought that enable these communities and individuals to exercise their rights, because evidence from these countries points to an unrestricted deployment of expressions of folklore in different art forms.

It must be pointed out that the tenor of the UNESCO Convention is in conflict with the free trade ethos of the World Trade Organisation, ${ }^{27}$ because the UNESCO Convention encourages protectionist measures in many dimensions. Academic opinion $^{28}$ is divided over this conflict and how the UNESCO Convention may be deployed in the compulsory dispute settlement of the WTO. A full consideration of these issues is beyond the scope of this paper, even though it must be stated that the conflict has brought the values of culture and trade into sharper focus.

\subsubsection{The UN Declaration on the Rights of Indigenous Peoples (DRIP)}

DRIP was adopted by General Assembly Resolution 61/295 on 13 September 2007 (recorded vote of 143 in favour to 4 against and 11 abstentions (including three African States - Burundi, Kenya and Nigeria). In understanding the significance of the DRIP I shall make reference to the 2007 Advisory Opinion of the African Commission on Human and Peoples' Rights ${ }^{29}$ on the United Nations Declaration of the Rights of Indigenous Populations ${ }^{30}$ in order to address a key issue that

Hereafter the WTO.

See a representative sample: Bruner "UNESCO, the WTO and Trade in Cultural Products"; Voon 2006 ICLQ and Hahn 2006 JIEL.

Hereafter ACHPR. The Advisory Opinion is available at http://bit.ly/f5vc0a.

Available at the Kenyan National Commission for Human Rights www.knhcr.org. The Advisory opinion was issued by the ACHPR in response to a decision by the Assembly of Heads of State and Government of the African Union in January 2007 requesting a deferment of deliberations by the UN General Assembly on the Draft Declaration on the Rights of Indigenous Peoples with a view to opening negotiations for making amendments in order to take into consideration the 
determines whether the DRIP can be of assistance to all communities in Africa or only to indigenous peoples. This is in accord with my position that Africa does not contain indigenous peoples and that all communities in Africa can be regarded as indigenous people. In the Advisory Opinion the ACHPR examined the definition of indigenous peoples and concluded that:

... a definition is not necessary or useful as there is no universally agreed definition of the term and no single definition can capture the characteristics of indigenous populations. Rather, it is much more relevant and constructive to try to bring out the main characteristics allowing the identification of the indigenous populations and communities in Africa. ${ }^{31}$

These characteristics were listed by the ACHPR as:

(i) Self Identification; (ii) A special attachment to and use of their traditional land whereby their ancestral land and territory have a fundamental importance for their collective physical and cultural survival as peoples; (iii) A state of subjugation, marginalization, dispossession, exclusion, or discrimination because these peoples have different cultures, ways of life or mode of production than the national hegemonic and dominant model. ${ }^{32}$

The Commission further pointed out that:

[I]n Africa, the term indigenous populations does not mean "first inhabitants" in reference to aboriginality as opposed to non-African communities or those having come from elsewhere. This peculiarity distinguishes Africa from the other Continents where native communities have been almost annihilated by non-native populations. Therefore, the ACHPR considers that any African can legitimately consider him/herself as indigene to the Continent. ${ }^{33}$

If every African is an indigene of the continent, the concept of indigenous people may be considered as being instrumental in that it helps to draw attention to groups and peoples who for different reasons have not been treated as other groups or enjoyed rights common to all groups. The Advisory Opinion recognises this point when it declares that:

fundamental preoccupations of African countries namely: a) the definition of indigenous populations; b) the issue of self-determination; c) the issue of land ownership and the exploitation of resources; d) the establishment of distinct political and economic institutions and e) the issue of national and territorial integrity.

Advisory Opinion, para 10.

Advisory Opinion, para 12.

Advisory Opinion, para 13. 
In Africa the term indigenous populations or communities is not aimed at protecting the rights of certain category of citizens over and above others. This notion does not create a hierarchy between national communities, but rather tries to guarantee the equal enjoyment of the rights and freedoms on behalf of groups, which have been historically marginalized. ${ }^{34}$

The multi-ethnic nature of African States makes it difficult to sustain a differentiation of the different groups. This point does not imply that all of the ethnic groups are treated alike. Historical, economic and social circumstances have resulted in the marginalisation of different groups of people. The remedy for this ill does not lie in creating a separate regime, but in insisting and ensuring that all groups are treated alike in theory and fact. The DRIP has added more impetus to the thrust to ensure that marginalised peoples are treated like other groups. The report of the African Commission's Working Group of Experts on Indigenous Populations/Communities ${ }^{35}$ has identified indigenous peoples and communities as consisting mainly of huntersgatherers and pastoralists. The Group identified a non-exhaustive list of these hunters-gatherers, which list includes the Pygmies of the Great Lakes Region, the San of Southern Africa, the Hadzabe of Tanzania, and the Ogiek of Kenya. ${ }^{36}$ The pastoralists are identified as the

... Pokot of Kenya and Uganda, the Barabaig of Tanzania, the Maasai of Kenya and Tanzania, the Samburu, Turkana, Rendille, Orma and Borana of Kenya and Ethiopia, the Karamojong of Uganda, the numerous isolated pastoralist communities in Sudan, Somalia and Ethiopia, to name but a few. West and Central Africa also have pastoralists such as the Touareg and Fulani of Mali, Burkina-Faso, Niger and the Mbororo who are spread over Cameroon and other West African countries. ${ }^{37}$

What these groups need is some measure of internal governance in different respects. The preamble to the DRIP states that the fundamental importance of the right to self determination is key to the protection of indigenous peoples. In interpreting a similar position in the Draft declaration, the Advisory Opinion states in paragraph 27 that:

Advisory Opinion, para 19.

African Commission's Working Group of Experts on Indigenous Populations/Communities 2005 www.iwgia.synkron.com.

36 African Commission's Working Group of Experts on Indigenous Populations/Communities 2005 www.iwgia.synkron.com para 15.

37 African Commission's Working Group of Experts on Indigenous Populations/Communities 2005 www.iwgia.synkron.com para 17. 
... the ACHPR is of the view that the right to self-determination in its application to indigenous populations and communities, both at the UN and regional levels, should be understood as encompassing a series of rights relative to the full participation in national affairs, the right to local selfgovernment, the right to recognition so as to be consulted in the drafting of laws and programs concerning them, to a recognition of their structures and traditional ways of living as well as the freedom to preserve and promote their culture. It is therefore a collection of variations in the exercise of the right to self-determination, which are entirely compatible with the unity, and territorial integrity of State Parties. ${ }^{38}$

More measures are needed to deal with indigenous peoples like minorities so that the concept of equality is not abstract and meaningless. It is to be remembered that the ethnic groups in the colonial state were marginalised because the colonial state was the dominant hegemonic group. All ethnic groups at independence entered the new State on an equal basis. Over the years one or another ethnic group in African States has achieved domination in one form or another. The fact is that in many of these countries there has been alternating marginalisation of ethnic groups to such an extent that all groups are likely to be marginalised sooner or later. This is another reason why they must be regarded as the same, even if they should actually be treated differently if cognisance is taken of their varying positions in society. The way to do this would be to grant them a large measure of autonomy, backed by adequate resources.

The legal character of the DRIP is another point worth considering because of the impact it will have on national models for the protection of indigenous peoples. There are two conflicting opinions as to the legal character of the DRIP. The States Canada, Australia, New Zealand and the USA - that voted against the Declaration hold one opinion. According to the representative of the Australian government:

[I]t was the clear intention of all States that it be an inspirational Declaration with political and moral force, but not legal force. The text contained recommendations regarding how States could promote the welfare of indigenous peoples, but was not in itself legally binding or reflective of international law. As the Declaration did not describe current State practice or actions considered themselves obligated to take as a matter of law, it could not be cited as evidence of the evolution of customary international 
law. The Declaration did not provide a proper basis for legal actions, complaints or other claims in any international domestic or other proceedings. ${ }^{39}$

There is no doubt that declarations are formal and solemn statements when principles of great importance are being enunciated, and that this method creates "a strong expectation that members of the international community will abide by it and consequently, in so far as the expectation is gradually justified by state practice, a declaration may be recognised as laying down rules binding on States." 40 It is therefore argued that the DRIP is not legally binding and does not create customary international law. Rather, as Stephen Allen argues, it was forged as a model for the legal regulation of indigenous issues at the municipal level. ${ }^{41}$

On the other hand there is academic opinion that DRIP represents customary international law. ${ }^{42}$ In a recent decision of the Belize Supreme Court in Maya $v$ Belize $^{43}$ the Court considered the DRIP as representing general principles of international law. ${ }^{44}$ With respect to the DRIP the Court stated in paragraph 131 that:

Also, importantly in this regard is the recent Declaration on the Rights of Indigenous Peoples adopted by the General Assembly of the United Nations on 13 September 2007. Of course, unlike resolutions of the Security Council, General Assembly resolutions are not ordinarily binding on member states. But where these resolutions or Declarations contain principles of general international law, states are not expected to disregard them. This Declaration - GA Res 61/295, was adopted by an overwhelming number of 143 states in favour with only four States against with eleven abstentions. It is of some signal importance, in my view, that Belize voted in favour of this Declaration.

39 61st General Assembly, 107th and $108^{\text {th }}$ Plenary Meetings, GA/10612, 13 September 2007 at p.5. See also statements by the USA at p. 7 .

40 UN Docs. E/CN.4/832/Rev.1,Para 105.

41 Allen 2009 www.ssrn.com

42 See generally Anaya Indigenous Peoples. See also Anaya and Wiessner 2007 www.jurist.law.pitt.edu

43 Aurelio Cal and the Maya Village of Santa Cruz v Attorney general of Belize; and Manuel Coy and Maya Village of Conejo v Attorney General of Belize, (Consolidated) Claim No. 171 and 172. Available at Supreme Court of Belize 2007 www.elaw.org.

44 A 26 of the DRIP states that: "1. Indigenous peoples have the right to the lands, territories and resources which they have traditionally owned, occupied or otherwise used or acquired. 2. Indigenous peoples have the right to own, use, develop and control the lands, territories and resources that they possess by reason of traditional ownership or other traditional occupation or use, as well as those which they have otherwise acquired. 3. States shall give legal recognition and protection to these lands, territories and resources. Such recognition shall be conducted with due respect to the customs, traditions and land tenure systems of the indigenous peoples concerned." 
And I find its Article 26 of especial resonance and relevance in the context of this case, reflecting, as I think it does, the growing consensus and the general principles of international law on indigenous peoples and their lands and resources. ${ }^{45}$

The significance of the DRIP reflecting customary international law lies in the fact that States become bound to implement the Declaration and therefore alter the national protection of indigenous peoples. It would appear that this is not yet settled, leaving it more likely that the DRIP is a model for States to follow.

The key provisions of the DRIP for our purposes are therefore important. Article 1 of the DRIP states that indigenous peoples have the right to the full enjoyment, as a collective or as individuals, of all human rights and fundamental freedoms as recognised in the Charter of the United Nations, the Universal Declaration of Human Rights and international human rights law. The right to cultural and intellectual property is articulated in a number of ways, first in Article 11(1) which provides that indigenous peoples have the right to practise and revitalise their cultural traditions and customs. This includes the right to maintain, protect and develop the past, present and future manifestations of their cultures, such as archaeological and historical sites, artefacts, designs, ceremonies, technologies and visual and performing arts and literature. Paragraph 2 of Article 11 directs States to provide redress through effective mechanisms, which may include restitution, developed in conjunction with indigenous peoples, with respect to their cultural, intellectual, religious and spiritual property taken without their free, prior and informed consent or in violation of their laws, traditions and customs. A second articulation can be found in Article 31(1) which provides that:

Indigenous peoples have the right to maintain, control, protect and develop their cultural heritage, traditional knowledge and traditional cultural expressions, as well as the manifestations of their sciences, technologies and cultures, including human and genetic resources, seeds, medicines, knowledge of the properties of fauna and flora, oral traditions, literatures, designs, sports and traditional games and visual and performing arts. They also have the right to maintain, control, protect and develop their intellectual property over such cultural heritage, traditional knowledge, and traditional cultural expressions. ${ }^{46}$ 
Again Article 31(2) directs States, in conjunction with indigenous peoples, to take effective measures to recognise and protect the exercise of these rights.

One of the rights specifically provided for is the right to privacy. Article 12(1) provides that indigenous peoples have the right to manifest, practise, develop and teach their spiritual and religious traditions, customs and ceremonies; the right to maintain, protect, and have access in privacy to their religious and cultural sites; the right to the use and control of their ceremonial objects; and the right to the repatriation of their human remains. It is clear that this right will go a long way in assisting indigenous peoples to maintain control over expressions of folklore, including expressions of a sacred nature or of especial significance.

The right to participation and consultation contained in Article 18 of the DRIP seeks to ensure that indigenous people have a fundamental input in how the State designs a model for their protection. Accordingly indigenous peoples have the right to participate in decision-making in matters which would affect their rights through representatives chosen by themselves in accordance with their own procedures, as well as to maintain and develop their own indigenous decision-making institutions. Article 19 requires States to consult and cooperate in good faith with the indigenous peoples concerned through their own representative institutions in order to obtain their free, prior and informed consent before adopting and implementing legislative or administrative measures that may affect them. One important way in which indigenous people can participate in protecting their intellectual property is through their normative systems. In this regard Article 34 of the DRIP provides that indigenous peoples have the right to promote, develop and maintain their institutional structures and their distinctive customs, spirituality, traditions, procedures, practices and, in the cases where they exist, juridical systems or customs, in accordance with international human rights standards.

Article 27 of the DRIP encapsulates the objective of a human rights protection model. The said article provides that States shall establish and implement, in conjunction with the indigenous peoples concerned, a fair, independent, impartial, open and transparent process, giving due recognition to indigenous peoples' laws, traditions, customs and land tenure systems, to recognise and adjudicate the rights 
of indigenous peoples pertaining to their lands, territories and resources, including those which were traditionally owned or otherwise occupied or used. Indigenous peoples shall have the right to participate in this process.

The rights of indigenous peoples are not absolute. Article 46 provides that indigenous people must exercise their rights within the context of the Charter of the United Nations and within the territorial integrity or political unity of sovereign and independent States. These limitations are to be determined by law and in accordance with international human rights obligations. Any such limitations shall be non-discriminatory and strictly necessary solely for the purpose of securing due recognition and respect for the rights and freedoms of others and for meeting the just and most compelling requirements of a democratic society.

\subsubsection{The right to culture in African States}

A number of African States protect the right to culture in their constitutions. For example in Uganda Section 37 of the 1995 Constitution of the Republic of Uganda provides that every person has a right as applicable to belong to, enjoy, practise, profess, maintain and promote any culture, cultural institution, language, tradition, creed or religion in community with others. In Malawi Section 26 of the 1994 Constitution of the Republic of Malawi provides that every person shall have the right to use the language and to participate in the cultural life of his or her choice. In South Africa Section 30 of the Constitution of the Republic of South Africa $1996^{47}$ provides that everyone has the right to use the language and to participate in the cultural life of their choice, but no one exercising these rights may do so in a manner inconsistent with any provision of the Bill of Rights. In addition Section 31 provides that persons belonging to a cultural, religious or linguistic community may not be denied the right, with other members of that community, to enjoy their culture, practise their religion and use their language; and to form, join and maintain cultural, religious and linguistic associations and other organs of civil society. In Ghana Section 26 of the Constitution of the Republic of Ghana 1992 provides that every

$47 \quad$ Hereafter the South African Constitution. 
person is entitled to enjoy, practise, profess, maintain and promote any culture, language, tradition or religion, subject to the provisions of the national Constitution.

It is clear that many African States take the view that cultural rights are individual rights with an indirect recognition given to the community and group, which must thrive and be sustained if the right granted to the individual is to have meaning. This viewpoint was recognised in the South African Constitutional Court decision in MEC Education KZN $\vee$ Pillay, ${ }^{48}$ which considered the constitutionality of a school's objection to a learner wearing a cultural and religious symbol. The majority judgment of the court considered the individual belief as central to the question of what beliefs and practices are to be recognised by the court. This would put the individual at the centre of the right to culture. On the other hand, with respect to Section 31 the majority judgment pointed out that Section 31 is based on Article 27 of the ICCPR and involves associative practices and not individual beliefs. ${ }^{49}$ These associative practices point to a collective right exercised by individuals in community with others. The minority judgment points out that:

In the anthropological sense, all human beings have a culture. Human beings live in communities and ordinarily share practices that make life meaningful to that community. Sections 30 and 31 of the Constitution protect the rights of individuals within communities to pursue cultural practices. There can be no doubt that these are important rights which protect diversity within our country. The rights, like all others in our Constitution, must be interpreted in light of the founding value of human dignity which asserts the equal moral worth of human beings and the right of each and every person to choose to live the life that is meaningful to them. Understanding the right to cultural life against the background of human dignity emphasises that the rights in sections 30 and 31 are associative rights exercised by individual human beings and are not rights that attach to groups. ${ }^{50}$

Perhaps on this reading it may be fair to argue that recognising a group's right to the protection of its expressions of folklore can manifest only if the individual members seek to protect that capital. This will be correct, but does not mean that the group cannot itself assert its right to this protection. What is significant about the minority judgment is a recognition that the correct way to approach culture is not through a consideration of the sincerely held beliefs of the individual, as urged by the majority,

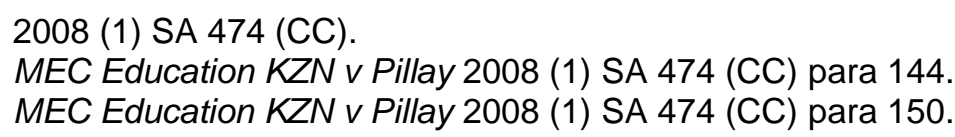


but on the basis of an "... an understanding of what the cultural community considers to be a cultural practice." ${ }^{51}$ Accordingly, if the cultural community asserts a right over its intellectual capital, this will be entirely consistent with the right to culture.

It must be pointed out that the majority decision in Pillay is clearly an affirmation of the liberal foundations of a South African human rights framework, which is built on an individual ethos. This is true of other African countries also, given the cast of their right to culture. This protection of culture is clearly not in accord with the manner in which the African Charter protects the right to culture. It is to be remembered that the African Charter recognises that all peoples are entitled to their cultural development. Clearly the minority judgment is far more in accord with the notion of the communal nature of traditional intellectual capital.

\subsubsection{Customary law as a component of the right to culture in African states}

One of the manifestations of the anthropological view of the right to culture is the recognition of the normative systems of cultural communities. If culture is the way of life of communities, it makes sense that the manner in which they order their lives and circumstances should be recognised. This normative system is usually referred to as customary law. For the purposes of this paper, customary law refers to the rules and processes by which communities protect their intellectual capital. One fundamental feature of customary law is that it is group oriented in the sense that it privileges the family and the community over the individual. For our purposes, we are concerned with customary law rules which protect the intellectual property of a community qua the community. ${ }^{52}$

Customary law in Africa predates the modern system of international human rights and is a direct result of colonialism. A tactic of European colonial rule in Africa was to recognise the norms of communities in the personal and family areas of the colonised communities. In addition they also used the traditional judicial authorities to adjudicate disputes among Africans. In the course of time, local courts constituted in the manner of the courts of the colonial countries were established to exercise the

$51 \quad$ MEC Education KZN v Pillay 2008 (1) SA 474 (CC) para 154.

52 See generally Kuruk 1999 Am U L Rev; Ametgatcher 2002 Copyright Bulletin. 
jurisdiction of these traditional authorities. In many courts, pre-colonial traditional judicial institutions are no longer in existence.

Even after independence the manner in which customary law has continued its operation resembles the colonial arrangement. In some countries like Ghana, ${ }^{53}$ Sierra Leone ${ }^{54}$ and South Africa, customary law is constitutionally recognised. Customary law is directly applicable in these countries, like other laws such as the common law. In other countries such as Nigeria, customary law is not directly recognised. It is indirectly recognised because the institutional structure of customary law is recognised in the 1999 Constitution of the Federal Republic of Nigeria ${ }^{55}$ by reason of the fact that Customary Court of Appeal can be established by any state that so desires. ${ }^{56}$ It is left to legislation to set out the framework for the application of customary law. ${ }^{57}$ In many of the countries where customary law is not directly applicable, it is subjected to validity tests which determine how and when customary law can be applied. For example, in Nigeria customary law is to be applied subject to three validity tests. ${ }^{58}$ The first is that customary law must not be repugnant to "natural justice, equity and good conscience"; the second is that it must not conflict with statutes; while the third is that it must be compatible with public policy. These validity tests represent the standards and values of the colonial masters and in many circumstances have ensured that customary law rules were struck down. A threshold question in the application of customary law rules for the protection of expressions of folklore is how expressions of folklore pass the different statutory validity tests.

53 See S 1(2) of the Constitution of the Republic of Ghana 1992 (hereafter the Ghana Constitution): "The common law of Ghana shall comprise the rules of law generally known as the common law, the rules generally known as the doctrines of equity and the rules of customary law including those determined by the Superior Court of Judicature." In s1(3) of the same Constitution "customary law" is defined as including the rules of law which by custom are applicable to particular communities in Ghana.

54 See S 170(2) of the Constitution of the Republic of Sierra Leone 1991 (hereafter the Sierra Leone Constitution), which provides that the common law of Sierra Leone shall comprise the rules of law generally known as the common law, the rules of law generally known as the doctrines of equity, and the rules of customary law, including those determined by the Superior Court of Judicature. S 170(3) defines customary law as the rules of law which by custom are applicable to particular communities in Sierra Leone. Hereafter the Nigerian Constitution.

See Ss 245 and 280 of the Nigerian Constitution.

See for example the Customary Court Law (Bayelsa State) 2006, Nigeria.

58 As an example see s16(1) of the High Court Law (Bayelsa State), which provides that the High Court shall observe and enforce the observance of customary Law which is not repugnant to natural justice, equity and good conscience, or incompatible either directly or by its implication with any written law from time to time in force in the state. 
There is also a constitutional validity test, because the constitutions of many African states are declared to be supreme and all other law inconsistent with it is declared null and void to the extent of the inconsistency. ${ }^{59}$ In most constitutions it is the fundamental human rights provisions that serve as a direct and relevant test of the validity of customary law rules. For example in South Africa Section 211(3) of the Constitution provides that the Courts must apply customary law when that law is applicable, subject to the Constitution and any legislation that specifically deals with customary law. In addition Section 8(1) provides that the Bill of Rights applies to all law, which includes customary law. It is largely the content of the Bill of Rights that is crucial in this regard.

In Africa two constitutional traditions in the protection of human rights may be said to exist. In countries like South Africa, whose rights are cast in favour of individuals, it is likely that the group-oriented nature of customary law will clash with the Bill of Rights. A South African Court faced with a claim by an individual for the exploitation of a communal expression of folklore could well rely on the Bill of Rights to justify the claim, since Pillay recognises that the Section 31 right has the individual in mind. Thus the recognition of customary law and its group-oriented ethos could in many instances fail human rights scrutiny unless the customary law could qualify as a limitation of the human right in terms of Section 36 of the South African Constitution. $^{60}$ Another tradition followed in countries like Nigeria ${ }^{61}$ is a cast of individual rights limited by group considerations such as public morality, public policy, public order and the like. In these countries there is a strong possibility that these group considerations will include the norms of communities and that this may be a way to legitimate the assertion of the community to the protection of its expressions of folklore, as against the individual.

Apart from the question of the validity of customary law and its application, customary law is also regarded as a question of fact. This means that customary law must be proved by evidence in court. After a number of applications the courts are

59 Eg S 1(3) of the Nigerian Constitution.

60 S v Makwanyane 1995 (3) SA 391 (CC).

61 S 45(1) of the Nigerian Constitution: "Nothing in Ss 37, 38, 39, 40 and 41 of this Constitution shall invalidate any law that is reasonably justifiable in a democratic society (a)in the interest of defence, public safety, public order, public morality or public health; or (b)for the purpose of protecting the rights and freedom of other persons." 
usually allowed to take judicial notice of customary law rules. One consequence of the proof of customary law is that the discretion of the judicial officer is fundamental in the recognition and ascertainment of customary law rules. This has led to a situation where the courts have recognised and interpreted customary law in a way that is far removed from the customary law which is found in the relevant communities. $^{62}$ Something like judicial customary law exists in South Africa, and is described as "official" customary law, because it involves the recording of customary law by government officials. ${ }^{63}$ It is thus possible that an asserted customary law rule will be rejected. In countries such as Ghana and South Africa, customary law is a question of law like other laws. Even though the content of customary law is supposed to be in the contemplation of the judge, the situation is the same because of the fact that customary law is oral and largely unwritten. Thus there is a need to prove customary law, just as in situations where customary law is regarded as a question of fact.

In many African countries, customary law is still restricted to the areas of inheritance, succession, chieftaincy, marriage, and the ownership and use of land and other natural resources. In many countries customary law is not applicable in the area of criminal law, because the oral nature of customary law will not satisfy the constitutional requirement that in order to ensure fair hearing all crimes must be an offence under either national or international law. ${ }^{64}$ The rules protecting expressions of folklore are not likely to be criminal and so will not be caught up by the rule requiring all criminal laws to be written. It can therefore be asserted that it is very likely that the oral rules of customary laws of communities protecting their expressions of folklore will be recognised.

While customary law is group oriented it has been individuals who have sought to use its rules, by claiming that their person and the expression of folklore fall within the contemplation of a customary law rule. There are no reported instances known to this author of communities who instituted actions to enforce rules of customary law in the protection of expressions of folklore. Even though communities are competent to

\footnotetext{
62 See generally Woodman "Customary Law State Courts" $143 \mathrm{ff}$.

63 Eg Bennett Human Rights and African Customary Law. See also Bhe v Magistrate Khayelista 2005 (1) SA 580 (CC) 81-87.

64 S 35(3)(I) of the South African Constitution.
} 
do so, it is obvious that proving the existence and content of a customary law rule on the expressions of folklore will not be an easy task.

In the next section I shall examine the existing protection of expressions of folklore in African States in the light of the above discussion. The discussion to follow is designed to show how a human rights regime will assist in overcoming some of the deficiencies in the national protection of expressions of folklore.

\section{An overview of the national protection of expressions of folklore in Africa}

In this part of the article I shall examine the two principal means by which expressions of folklore are protected in Africa in order to develop a context in which the utility of a human rights protective regime can be better appreciated.

At independence in the sixties, African countries adopted the intellectual property laws of their colonial masters, which included copyright law. During the early seventies, the importance of expressions of folklore as the basis of cultural identity and as a source of creativity and wealth creation became obvious to African countries and developing nations generally. It would appear that African countries were part of a movement by developing countries to protect the rights of indigenous peoples. Later, the incipient digital revolution that facilitated and enhanced the improper exploitation of expressions of folklore on a massive scale brought home the reality of the need for some manner of protection for expressions of folklore.

\subsection{The sui generis protection of expressions of folklore in African countries}

The inability of the Berne Convention for the Protection of Literary and Artistic Works $1886^{65}$ to effectively deal with the protection of expressions of folklore led to calls for better protection. The Berne Convention had first discussed the protection of expressions of folklore at the Stockholm revision conference in 1967. It adopted

65 Paris Text 1971. Hereafter the Berne Convention. 
Article $15(4)^{66}$ as a summary of the work of a committee charged with overseeing the possibility of including the protection of folklore in the treaty. Article 15(4) did not even mention folklore by name and required a designation of national authority to protect unpublished works which, on evidence, appear to have been made by a national of that country. Further steps were advocated in developing a protection regime. In 1976 a Committee of Governmental Experts of WIPO and UNESCO adopted a Model Law on Copyright for Developing Countries. ${ }^{67}$ The Tunis Model Law dealt with folklore as part of a regime of copyright protection. There is little doubt that the provisions of the Berne Convention and the Tunis Model Law influenced the earliest legislation by African countries to protect expressions of folklore through copyright legislation, an example of which is to be found in Senegal. ${ }^{68}$ Even then, the protection granted to expressions of folklore recognised folklore as a cultural heritage of the nation and required authorisation before it could be fixated or performed by foreigners. To say the least, this protection was inadequate because it was not well elaborated. Even though protection was contained in the copyright legislation of these African countries ${ }^{69}$, there is no convincing evidence of any serious attempt to deploy the principles of copyright or legal protection of intellectual property for the benefit of folklore. Perhaps this was due to the obstacles to such protection of expressions of folklore, which include the questions of originality, fixation and duration.

Another milestone in the search for a protective regime for folklore protection occurred in 1982 when the United Nations Educational Scientific and Cultural Organization (UNESCO) and WIPO adopted The Model Provisions for National Laws on the Protection of Expressions of Folklore Against Illicit Exploitation and Other

66 A 15(4) of the Berne Convention provides that "(a) In the case of unpublished works where the identity of the author is unknown, but where there is every ground to presume that he is a national of a country of the Union, it shall be a matter for legislation in that country to designate the competent authority which shall represent the author and shall be entitled to protect and enforce his rights in the countries of the Union.(b) Countries of the Union which make such designation under the terms of this provision shall notify the Director General by means of a written declaration giving full information concerning the authority thus designated. The Director General shall at once communicate this declaration to all other countries of the Union." Hereafter the Tunis Model Law, accessible at See http://bit.ly/fdfqxM.

68 See A 9 of the Senegalese Copyright Act 1973: "Folklore shall belong originally to the national cultural heritage."

69 See for example the Copyright Act (Chapter 30 of the Laws of Kenya) 1975. 
Prejudicial Actions. ${ }^{70}$ This influential document recommended a sui generis protection of expressions of folklore and influenced the cast of the protection in the second generation African copyright legislation - Nigeria $^{71}$; Malawi ${ }^{72}$; Kenya ${ }^{73}$; Tanzania $^{74}$; Cameroon ${ }^{75}$; Botswana ${ }^{76}$; Ghana ${ }^{77}$; Cote D'Ivoire ${ }^{78}$ and Mozambique ${ }^{79}$. It is significant that African countries legislated the Model Law in different interpretations as part of their copyright and neighbouring rights legislation. The Model Law provides for principles of protection; the scope of subject matter; the utilisations subject to authorisation; the manner of obtaining authorisation; the exceptions and limitations to authorisations; the moral rights attached to copyright; civil and criminal sanctions; the designation of the competent authority to administer copyright; and the protection of expressions of folklore of foreign countries. Available evidence reveals a negligible recourse to the protection offered by the sui generis laws of these African countries. ${ }^{80}$ One major reason for this state of affairs is that the protection of the expressions of folklore is vested in and administered by the State or its agency and not by the communities that own the expressions of folklore. Thus, in Nigeria it is the Nigerian Copyright Commission; in Ghana it is the National Folklore Board; in Tanzania it is the National Arts Council of Tanzania; and in Mozambique it is the State. In Senegal, Cote d'Ivoire and Cameroon it is also the State, but the management is vested in the national collecting societies. The Copyright Society of Malawi (COSOMA) manages Malawian expressions of folklore.

It may be said that the practice of embedding folklore protection within copyright protection is responsible for the low level of protection of expressions of folklore. For example, the designation of the national copyright authorities and other organs of State as the competent authority to protect folklore invariably ties the latter to the

Hereafter Model Law. Doc. No WIPO/GRTKF/IC/2/7, accessible at http://bit.ly/eEbFMv.

Copyright Act (Chapter 28 of the Laws of Nigeria) 2004.

Copyright Act 9 of 1989.

Copyright Act 12 of 2001.

Copyright and Neighbouring Rights Act 6 of 1999.

Law No 2000/011 on Copyright and Neighbouring Rights.

Copyright and Neighbouring Rights Act 2000.

Copyright Act (690) 2005.

Law on the Protection of Intellectual Works and Rights of Authors, Performers and Phonogram and Videogram Producers (Law 96-254) 1996.

Law No. 4/2001 Approving Copyright.

Eg Ludewig 2009 Michigan Journal of Public Affairs 13. The author asserts that a folklore tariff has been enforced three times since 1985. The folklore tariff was introduced by the now repealed Copyright Act of 1985 as part of the conditions for the approval for the use of expressions of folklore in Ghana. The present Copyright Act 2005 retains the imposition of a folklore tariff. 
competence and capacity of that office. The diverse demands on poorly resourced national copyright offices for attention by other equally important copyright issues such as piracy leave many of these offices incapable of enforcing and often unwilling to enforce the provisions on the protection of expressions of folklore.

The extent to which members of an ethnic community or members of other ethnic communities in the same State could use an expression of folklore remains a problem. The status of derivative works produced from expressions of folklore with appropriate permission is also a problem. So is the manner of exceptions and limitations that do not require authorisation. Are these to be determined by the context in which the expression of folklore is used, or are they to be determined by the same standards - such as fair use or fair dealing - by which exceptions and limitations to copyright are generally determined by copyright legislation? In this regard are sacred types of expressions of folklore to be completely secluded from the public? What constitutes an appropriate manner of acknowledging the moral rights of communities? There is therefore a strong need to amend these national legislations in the light of the experience of over two decades of its publication and use. It is clear that these amendments can be very effective if informed by a clarification of the nature of the human rights of communities in the protection of their expressions of folklore.

\subsection{The protection of expressions of folklore by intellectual property law}

There is a strong possibility that expressions of folklore can be protected by intellectual property law such as copyright and neighbouring rights; trademarks; patents and designs; and geographical indications. Of all of these intellectual property laws, the principles of copyright protection appear most easily adaptable to the protection of expressions of folklore, in spite of the negative aspects of copyright protection considered above.

A number of African countries protect expressions of folklore as species of copyright. Thus in Seychelles Section 7 of the Copyright $A c t^{81}$ provides that copyright subsists

81 The Copyright Act (Chapter 51 of the Revised Laws of Seychelles) 1991. 
in every work eligible for copyright which is Seychelles folklore. The copyright subsists in perpetuity and vests in the State. Licences may be granted by the Minister in charge of culture and cannot be transferred by assignment or otherwise. Any purported assignment is void. In Mauritius the protection of expressions of folklore is predicated on the definition of the expression of folklore by the Copyright Act as meaning productions of characteristic elements of traditional artistic heritage developed and maintained by a community or by individuals reflecting the traditional artistic expectations of a community. Accordingly Section 3(1) of the Copyright Act provides copyright protection for expressions of folklore through its designation as a derivative work which is defined as "a translation, adaptation, arrangement or other alteration of a pre-existing artistic literary or scientific work and includes a collection or compilation of expressions of folklore or of mere facts or data."

Since some of the expressions of folklore can be performed, it is possible that if the performers are from the relevant community they can receive the protection offered to performers in respect of their performance and related acts such as its fixation, recording and broadcasting. An example of this type of protection can be found in Section 28(2) of the Ghana Copyright Act; Section 24 of the Mauritius Copyright Act; Section 24 of the Copyright and Neighbouring Rights Act of Botswana and the Performers' Protection Act ${ }^{83}$ of South Africa.

Other possibilities of intellectual property law that can be deployed to protect expressions of folklore ${ }^{84}$ include the use of certification trademarks; the use of the action of breach of confidence in common law countries; the use of equitable licenses; the use of collecting societies; and the principles of unfair competition.

Case law from Australia and Canada points to the difficulty of deploying copyright in the protection of expressions of folklore for a number of reasons. First is the question of ownership. While copyright law protects individual ownership, expressions or folklore are communally owned. In the Australian case of Yumbulul v Reserve Bank

See Visser 2002 SA Merc LJ for an excellent review of the possibilities. 
of Australia $^{85}$ the Court pointed out that copyright law does not provide adequate recognition of Aboriginal communal claims. Some limited success was recorded in the case of Milpurrurru $v$ Indofurn Pty Ltd, ${ }^{86}$ where a group of Aboriginal painters instituted a copyright infringement case for an unauthorised use of sacred aboriginal paintings in a carpet. Secondly, copyright law usually requires fixation in any material form, while a large part of folklore is oral. Related to this point is the fact that expressions of folklore often lie between ideas and expression and make it difficult to afford copyright protection to them. Thirdly, copyright protection is limited in duration - usually the author's life and fifty years after the author's death - while expressions of folklore are often timeless and would suffer because they have no identifiable author, and also because some of the expressions of folklore are made in an incremental manner over a long period of time. Fourthly the works that are derived from expressions of folklore can become subject to copyright protection and be protected on their own. Such copyright protection has been the principal form of misappropriation of expressions of folklore. When a copyright work embodies an expression of folklore, the consequence is that the copyright owner has the right to bar or restrict how the community can use the expression of folklore they created. Accordingly a community that seeks to use its own expression of folklore without permission is a copyright infringer.

When it is remembered that national intellectual property regimes are a matter of legislation, this brings to mind the possibility that they can be amended to accommodate expressions of folklore. ${ }^{87}$ With respect to copyright, a few examples can illustrate the changes that can be made. The requirement of originality may be maintained in the form in which it is at present, because it is generally cast at a low level, which may enable expressions of folklore that are not of high artistic quality to qualify for copyright protection. It is not the artistic quality of an expression of folklore that defines the work, but the identification by a community that a work is an expression of folklore. Some possibilities in copyright reform with respect to expressions of folklore include the recognition of representatives of communities as the owners of the copyright; doing away with the question of the duration of

Yumbulul v Reserve Bank of Australia (1991) 21 IPR 481.

Milpurrurru v Indofurn Pty Ltd (1995) 30 IPR 209; Blakeney 1995 www.murdoch.edu.au.

An example of this type of legislative intervention is to be found in the Draft Intellectual Property Amendment Act 2008 of South Africa, which is currently before Parliament. 
expressions of folklore as an exception to the limited duration of copyright; and doing away with the requirement of fixation in any material form. Whether these amendments are possible, feasible or appropriate is another question.

To sum up this part of the article, a properly articulated human rights regime will assist in the refinement of either a sui generis or an intellectual property protection of expressions of folklore. Such a regime is advisable because it operates with an inherent concern and commitment to an appropriate balance between the private interests of communities in protecting their expressions of folklore and the public interest in accessing these resources. The practical challenges that a human rights regime would confront include establishing the matter of determining who qualifies as a community, and the criteria according to which such a determination would be made. It would also be difficult to establish whether the State or the traditional communities would be a better agency of protection. Because of the liberal foundation of modern African societies there will always a need to give careful consideration to setting out how Individuals interact with their communities with respect to the use of expressions of folklore. Another practical challenge would be the determination of the content of customary law, which governs interaction with communal intellectual property. Another issue to consider would be the extent to which contractual obligations can modify the rights of communities.

A fundamental advantage of opting for a human rights regime would be the range of remedies which would be available to the communities seeking to protect their expressions of folklore. A number of challenges remain with respect to the appropriate remedies. The first is to what extent compulsory compensation schemes could work. The second relates to collecting societies. Would they negate human rights. and how could they assist communities, if at all? A third challenge is whether national human rights institutions, national copyright institutions, or administrative agencies are better suited to mediate between third parties and communities through informal means rather than courts. Deeper reflections on these challenges are needed to enable a better understanding of how a human rights regime could assist communities in the protection of their expressions of folklore. 


\section{$4 \quad$ Concluding remarks}

The assertion that group and collective rights should be recognised and promoted is not one that liberal African States seem very enthusiastic about, despite their subscription to the African Charter of Human and Peoples' Rights. Recent events examined above with respect to the expressions of folklore point to a change in this attitude, albeit in a slow, incremental form. This is commendable, as it should complement the clear and firm desire by African States to protect expressions of folklore by sui generis models or through intellectual property law. A human rights regime would assist, clarify, enhance and reform the existing protection of the intellectual endeavour of communities in African States. 


\section{Bibliography}

Ametgatcher 2002 Copyright Bulletin

Ametgatcher A "Protection of Folklore by Copyright - a contradiction in terms" 2002 Copyright Bulletin 33-42

Anaya Indigenous Peoples

Anaya SJ Indigenous Peoples in International Law (Oxford University Press New York 2004)

Bennett Human Rights and African Customary Law

Bennett T Human Rights and African Customary Law under the South African Constitution (Juta Cape Town 1997)

Brunner "UNESCO, the WTO and Trade in Cultural Products"

Bruner CM "UNESCO, the WTO and Trade in Cultural Products" in Chaisse $\mathrm{J}$ and Balmelli T (eds) Essays on the Future of the WTO: Vol. II Policies and Legal Issues (EDIS Geneva 2008) 385-424

Coombe 1998 Ind J of Global Leg Stud

Coombe R "Intellectual Property, Human Rights and Sovereignty" 1998 Ind J of Global Leg Stud 59-115

Drahos 2000 EIPR

Drahos P "Indigenous Knowledge, Intellectual Property and Bio-Piracy: Is a Global Collecting Society the Answer?" 2000 EIPR 245-250

Graber "Traditional Cultural Expressions"

Graber CB "Traditional Cultural Expressions in a Matrix of Copyright, Cultural Diversity and Human Rights" in Macmillan F (ed) New Directions in Copyright Law Vol.5 (Edward Elgar Cheltenham 2007) 45-71 
Hahn 2006 JIEL

Hahn M "A Clash of Cultures? The UNESCO Diversity Convention and International Trade Law" 2006 JIEL 515-552

Helfer 2007 UC Davis L Rev

Helfer L "Towards a human rights framework for intellectual property" 2007 UC Davis L Rev 971-1020

Kuruk 1999 Am $U L$ Rev

Kuruk P "Protecting Folklore Under Modern Intellectual Property Regimes: A Reappraisal of the Tensions Between Individual and Communal Rights in Africa and United States" 1999 Am U L Rev 769-840

Kymlicka Multicultural Citizenship

Kymlicka W Multicultural Citizenship: A Liberal Theory of Minority Rights (Clarendon Oxford 1995)

Ludewig 2009 Michigan Journal of Public Affairs

Ludewig K "The nationalization and commercialization of Ghanaian folklore" 2009 Michigan Journal of Public Affairs 1-38

Margalit and Halbertal 1994 Social Research

Margalit A and Halbertal M "Liberalism and the Right to Culture" 1994 Social Research 491-510

Nwauche 2005 Script-ed

Nwauche ES "The Protection of Expressions of Folklore through the Bill of Rights in South Africa" 2005 Script-ed 224-255

O'Keefe 1998 ICLQ

O'Keefe R "The Right to Take Part in Cultural Life Under Article 15 of the ICESCR" 1998 ICLQ 904-923 
Stavenhagen "Cultural Rights and Universal Human Rights"

Stavenhagen R "Cultural Rights and Universal Human Rights" in Eide A, Krause C

Rosas A (eds) Economic, Social and Cultural Rights: A Textbook (Martinus Nijhoff Dordrecht 1995) 63-77

Visser 2002 SA Merc LJ

Visser C "Some Thoughts on Making Intellectual Property Work for Traditional Knowledge" 2002 SA Merc LJ 656-687

Voon 2006 ICLQ

Voon T "UNESCO and the WTO: A Clash of Cultures?" 2006 ICLQ 635-651

Woodman "Customary Law State Courts"

Woodman G "Customary Law State Courts and the Notion of Institutionalisation of Norms in Ghana and Nigeria" in Allott A and Woodman G (eds) Peoples' Law and State Law: The Bellagio Papers (Foris Dordrecht 1985) 143-163

Yu 2007 Ga St U L Rev

Yu PK "Ten common questions about intellectual property and human rights" 2007 Ga St U L Rev 709-753

\section{Register of legislation}

\section{Africa}

African Charter on Human and Peoples' Rights 1981

\section{Botswana}

Copyright and Neighboring Rights Act 2000

\section{Cameroon}

Law No. 2000/011 on Copyright and Neighboring Rights

\section{Cote d'Ivoire}

Law on the Protection of Intellectual Works and Rights of Authors Performers Phonogram and Videogram Producers (Law 96-24)1996 


\section{Ghana}

Constitution of Republic of Ghana 1992

Copyright Act (690) 2005

\section{Kenya}

Copyright Act (Chapter 30 of the Laws of Kenya) 1975

Copyright Act 12 of 2001

\section{Malawi}

Constitution of the Republic of Malawi 1992

Copyright Act 9 of 1989

\section{Mauritius}

Copyright Act 12 of 1997

\section{Mozambique}

Law No 4/2001 Approving Copyright

\section{Nigeria}

Constitution of Federal Republic of Nigeria 1999

Copyright Act Nigeria (Chapter 28 of the Laws of the Federation of Nigeria) 2004

Customary Court Law (Bayelsa State) 2006

High Court Law (Bayelsa State) 2006

\section{Senegal}

Copyright Act (Law 73-52) 1973

\section{Seychelles}

Copyright Right Act (Chapter 51 of the Revised Laws of Seychelles) 1991

\section{Sierra Leone}

Constitution of the Republic of Sierra Leone 1991

\section{South Africa}

Constitution of the Republic of South Africa 1996

Copyright Act 98 of 1978

Performers' Protection Act 11 of 1976

\section{Tanzania}

Copyright and Neighboring Rights Act 6 of 1999

\section{Uganda}

Constitution of the Republic of Uganda 1995 


\section{International}

Berne Convention for the Protection of Literary and Artistic Works (Paris Text) 1971

International Covenant for Civil and Political Rights 1966

International Covenant for Economic Social and Cultural Rights 1966

UNESCO Convention on the Protection and Promotion of the Diversity of Cultural

Expressions 2005 (see UNESCO 2005 www.unesco.org under Register of Internet resources)

United Nations Declaration on the Rights of Indigenous Peoples 2007

Universal Declaration of Human Rights 1948

\section{Register of cases}

\section{Australia}

Milpurrurru v Indofurn Pty Ltd(1995) 30 IPR 209

Yumbulul v Reserve Bank of Australia(1991) 21 IPR 481

\section{Belize}

Aurelio Cal and the Maya Village of Santa Cruz v Attorney General of Belize; and Manuel Coy and Maya Village of Conejo $v$ Attorney General of Belize, (Consolidated) Claim No. 171 and 172 (See Supreme Court of Belize 2007 www.elaw.org under Register of Internet sources)

\section{South Africa}

Bhe v Magistrate Khayelista 2005 (1) SA 580 (CC)

MEC Education KZN v Pillay 2008 (1) SA 474 (CC)

S v Makwanyane 1995 (3) SA 391 (CC).

\section{Register of Internet resources}

African Commission Working Group of Experts on Indigenous Populations/Communities 2005 www.iwgia.synkron.com

African Commission Working Group of Experts on Indigenous Populations/Communities 2005 Report www.iwgia.synkron.com/graphics/synkron- 
library/Documents/publications/Downloadpublications/Books/AfricanCommissionBoo kEnglish.pdf [date of use 15 Aug 2009]

Allen 2009 www.ssrn.com

Allen S "The UN Declaration on the Rights of Indigenous Peoples and the Limits of the International Legal Project in the Indigenous Context - Abstract" in Allen $S$ and Xanthaki A (eds) Reflections on the United Nations Declaration on the Rights of Indigenous Peoples and International Law (Oxford Hart forthcoming 2011) www.ssrn.com/abstract=1497946 [date of use 20 Oct 2010]

Anaya and Wiessner 2007 www.jurist.law.pitt.edu

Anaya SJ and Wiessner S 2007 The UN Declaration on the Rights of Indigenous Peoples: Towards Re-empowement www.jurist.law.pitt.edu/forumy/2007/10/undeclaration-on-rights-of-indigenous.php [date of use 16 Aug 2009]

Blakeney 1995 www.murdoch.edu.au

Blakeney M "Milpurrurru and Ors v Indofurn Pty Ltd and Ors: Protecting Expressions of Folklore Under Copyright Law" 1995 Murdoch University Electronic Law Journal 2(1) www.murdoch.edu.au/elaw/issues/v2n1/blakeney21.html [date of use 20 Oct 2010]

Kenyan National Commission for Human Rights www.knhcr.org

Kenyan National Commission for Human Rights www.knhcr.org/dmdocuments/ACHPR_Advisory_Opinion.pdf [date of use 13 Aug 2009]

Niec 2002 www.dba.es

Niec H 2002 Cultural Rights: At the End of the World Decade for Cultural Development www.dba.es/cerc/interaccio2002/seminar/s6/docu10.htm [date of use 25 Aug 2009]

OHCHR CESCR www.ohchr.org

OHCHR CESCR (date unknown) General Comment No 17: The Right of Everyone to Benefit from the Protection of the Moral and Material Interests Resulting from any 
Scientific, Literary or Artistic Production of Which He or She is the Author (Art. 15, Para. 1 (c) of the Covenant) www.ohchr.org/english/bodies/cescr/comments.htm [date of use 25 Aug 2009]

Supreme Court Belize 2007 www.elaw.org

Supreme Court Belize 2007 Aurelio Cal and the Maya Village of Santa Cruz v Attorney General of Belize; and Manuel Coy and Maya Village of Conejo v Attorney General of Belize, (Consolidated) Claim No. 171 and 172 www.elaw.org/node/1620 [date of use 16 Aug 2009]

UNESCO 2005 www.unesco.org

UNESCO 2005 Convention on the Protection and Promotion of the Diversity of Cultural Expressions (U.N. Doc CLT-2005/CONVENTION DIVERSITE-CULT REV.) www.unesdoc.unesco.org/images/0014/001429/142919e.pdf [date of use 21 Oct 2010]

WIPO 1984 www.wipo.int

WIPO 1984 Draft Treaty on the Protection of Expressions of Folklore www.wipo.int/export/sites/www/tk/en/consultations/draft_provisions/pdf/tce-

provisions.pdf [date of use 20 Aug 2009]

\section{List of abbreviations}

ACHPR

Am U L Rev

CESCR

DRIP

EIPR

Ga St U L Rev

$\mathrm{GC}$

ICCPR
African Commission on Human and Peoples' Rights

American University Law Review

Committee on Economic, Social and Cultural Rights (OHCHR)

United Nations Declaration of the Rights of Indigenous People

European Intellectual Property Reports

Georgia State University Law Review

General Comment

International Covenant for Civil and Political Rights 
ICESCR International Covenant for Economic Social and Cultural Rights

ICLQ

International and Comparative Law Quarterly

Ind J of Global Leg Stud Indiana Journal of Global Legal Studies

JIEL

Journal of International Economic Law

$\mathrm{OHCHR}$

Office of the United Nations High Commissioner for

Human Rights

SA Merc LJ

South African Mercantile Law Journal

UC Davis L Rev

University of California (Davis) Law Review

UDHR

Universal Declaration of Human Rights

UN

United Nations

UNESCO

United Nations Educational, Scientific and Cultural Organisation

UNESCO Convention

UNESCO Convention on the Diversity of Cultural Expressions

WIPO

World Intellectual Property Organisation

WTO

World Trade Organisation 